\title{
A magyar szociológia története - külföldieknek, az adatok nyelvén
}

\author{
Victor Karády - Péter Tibor Nagy: Sociology in Hungary. A Social, \\ Political and Institutional History. Sociology Transformed. Series \\ Editors: John Holmwood, Stephen Turner. Palgrave Mac Millan, \\ 2019. 198 oldal
}

Karády Viktor és Nagy Péter Tibor évtizedek óta számítanak a hazai értelmiségtörténet jelesei közé. Mostani vállalkozásuk azt célozza, hogy a magyar szociológia történetét tárják angol nyelven az olvasók elé. Egészen pontosan - amint az a könyv alcíméből is kiderül - a magyar szociológia társadalom-, politika- és intézménytörténetét.

Mindez természetesen meghatározza és le is határolja, hogy a szerzőpár ambíciói mire nem terjednek ki. A Sociology in Hungary. A social, political and institutional history, ami 2019-ben jelent meg a Palgrave McMillannél a Sociology Transformed nevet viselö országtanulmány-sorozatban, nem törekszik arra, hogy magyar szociológusok életmúvét, hazai szociológiai irányzatokat, elméleteket elemezzen. Az is egyértelmű, hogy a könyv elsősorban a külföldi közönségnek készült. Azt viszont egyértelmű célként tüzték maguk elé, hogy felvázolják a honi szociológia létrejöttének és fejlődésének társadalmi hátterét, politikai keret- és feltételrendszerét, és mindezt institucionalista megközelítésből tegyék. Karády és Nagy munkásságát ismerve az olvasó pedig azt is feltételezhette, hogy mindehhez statisztikai felkészültségüket is kamatoztatják majd. Már elöljáróban leszögezhetjük: a kötet ezeket a várakozásokat teljesíti is.

A Sociology in Hungary - részben a nem magyar publikum informálása végett - az ország történelmének rövid ismertetésével indít, természetesen a modern korra koncentrálva, egyúttal a modernizáció és az alulfejlettség, a centrum-periféria problematikájára kihegyezve. Karády és Nagy aláhúzza: a dualizmus korában bekövetkezett nagyarányú fellendülés az értelmiségi pályákon és a társadalomtudományokban (statisztika, jogtudomány, néprajz, közgazdaságtan) lehetővé tette

A szerző szociológus, habilitált egyetemi docens a Szeged Tudományegyetem Bölcsész- és Társadalomtudományi Karának Szociológia Tanszékén. E-mail: balog.ivan56@gmail.com 
a felzárkózást a legfejlettebb országokhoz, ezáltal megteremtve a szociológia, mint önálló diszciplína kifejlődésének előfeltételeit. Elkezdődött ugyanakkor az értelmiségi túltermelés, s ez radikalizálódáshoz vezetett, ekkor még csak a baloldalon, ami erőteljesen érződött a szociológia első magyar műhelyének arculatán is - ez viszont rögtön kiváltotta a jobboldali establishment ellenséges reakcióját. Ezzel összefüggésben már itt, az első fejezetekben érződik a könyv egyik fő küldetése: megértetni a nyugat-európai és amerikai olvasóval, hogy Kelet-Közép-Európában, a demokráciadeficittel küzdő országokban a szociológia fejlődését a hatalom nagyon sokszor korlátozta, sőt, helyenként kifejezetten tiltotta is, és ezért a magyar szociológiatörténet a kényszerü törések, szakadások, a diszkontinuitások históriája. További nehézségeket okozott a szociológia első magyar mühelyén belüli 1906-os, tragikus skizma, amelyhez nagyban hozzájárult az a skizofrén helyzet is, amelyet a kiegyezés jogi zsákutcájában a darabontkormányt a felszínre dobó belpolitikai válság idézett elő. A szakítás következtében ettől kezdve kétféle szociológia alakult ki, megkettőzött intézményrendszerrel: egy jobboldali, nacionalista, és egy radikális, baloldali, a jobboldalinál jóval több zsidó származású szereplővel. Ez a probléma, amely mind Karády Viktort, mind pedig Nagy Péter Tibort régóta foglalkoztatja, a forradalmak után a Horthy-korszakban egyre jobban rányomta a bélyegét a szakma fejlődésére - egészen egyszerüen úgy, hogy az októberi forradalomban és a kommünben részt vett, többnyire zsidó származású szociológusokat külső vagy belső emigrációra kényszerítette.

A Horthy-korszak elitjének viszonyulása a szociológiához ezzel együtt nem kizárólag ellenséges, hanem inkább ambivalens volt. Az autoriter rendszerekben gyakran megfigyelhető jelenség, hogy korlátozzák, de nem számolják fel teljesen a pluralizmust: restrikciókat, de nem totális cenzúrát alkalmaznak a nyilvánosságban, és eltürik egyfajta félellenzék müködését, miközben az igazi oppozícióval kíméletlenül szembeszállnak. Ennek a hibrid mentalitásnak a szellemében szelektív a viszonyuk a reformkezdeményezésekhez is: az „építő”, „mérsékelt” társadalomjobbítást tolerálják, és helyenként felülről bátorítva vagy korrumpálva igyekeznek becsatornázni. Ez lecsapódik a szociológiához való viszonyulásban is, elvégre a szociológia reformtudomány, de egyaránt lehet a radikális és a mérsékelten reformáló social engineering tudománya is. Így alakult ki a horthysta kurzuson belül a reformkonzervativizmus, amely a szociológiában is igyekezett kialakítani hídfóállásait. A szociológia iránti attitüd tetten érhető abban is, ahogyan egyfajta babonás szómágiával még a „szociológia” kifejezés puszta használatát is kerülni igyekeztek. A Horthy-korszak elitje felismerte ugyanakkor, hogy a vesztes világháború és gazdasági válságok után, a tömegtársadalmak korában az újabb forradalmak elkerülése céljából szükség van szociálpolitikára. A totalitárius és a tekintélyuralmi rendszerek ebben a korban egyébként is gyakran fejlettebb szociálpolitikai rendszereket alakítottak ki, mint a polgári demokráciák, amelyek ekkor még nem építették ki a jóléti államot. Ennek tudható be, hogy - amint azt 
a könyv szerzői is kiemelik - ebben a korban a szociálpolitikusok körében nem egy felkészült szakembert találhatunk. Ironikus, hogy hozzájuk képest a harmincas évek legprogresszívabb társadalomkutatói, a falukutató mozgalom szociográfusai amatőröknek minősültek. Mivel a rendszer balfelé zárt jellegéből következően a reformszándékokat csak a jobboldal aknázhatta ki, a szociológia intézményesülése ebben a feltételrendszerben csak korlátozott lehetett, és paradox módon akkor gyorsult fel bizonyos fokig, amikor Magyarországhoz olyan országoktól csatoltak vissza területeket, ahol e tudományág fejlettebb volt. Igaz, még ekkor is vigyáztak arra, nehogy a „szociológia” szóval illessék az újonnan alakult tanszékeket.

A szociológia iránti felemás viszony a koalíciós időszakban is megmaradt. Bár a zsidó származásúakat és a baloldaliakat sújtó diszkrimináció megszűnt, az inga visszalengésével párhuzamosan éppen az egyre nagyobb befolyásra szert tevő kommunista párt részéről érte mind több támadás a diszciplína függetlenedését és intézményesülését azon az alapon, hogy - úgymond - a marxizmus az egyedüli igazi szociológia, és a polgári szociológia csak a burzsoázia érdekeit szolgálja, mert elfedi a legégetőbb társadalmi konfliktusokat. A kommunista diktatúra bevezetésekor ez pedig az alig éledezni kezdett szociológia burzsoá áltudománnyá nyilvánításához és kifejezett betiltásához vezetett, ami ismét sokakat lehetetlenített el egzisztenciálisan - és a jobbik eset volt az, ha megúszták azzal, hogy külföldre távoztak. Ebből is látszik: a diktatúrák nem akarják meghallani a rossz híreket, és a hírhozókat büntetik meg miattuk, mert társadalmi problémáikat az ellenség aknamunkájának tulajdonítják.

Mivel a szociológia indexre tétele a sztálinizmus produktuma volt, lassú és részleges megtürése és engedélyezése is ideológiai fordulatnak: a desztalinizációnak köszönhető, és ahogy a tudományág ellenséggé nyilvánítása, úgy az iránta való békülékenyebb attitüd is a Szovjetunióból eredt. A másik e szempontból mintaadó ország a béketáborban Lengyelország volt, ahol már az ötvenes években sem sújtottak le olyan keményen a szociológusokra, mint másutt. Mindehhez egy belső tényező is társult: a Kádár-rendszer pragmatizmusa és ezzel párhuzamosan növekvő dezideologizáltsága az ,,aki nincs ellenünk, az velünk van” elv szellemében, továbbá elkötelezettsége a gazdasági - de nem a politikai! - reformok iránt. A reformszándékok pedig még egy egypártrendszerü diktatúrában is enyhíteni voltak képesek az ellenzéki professzió hírében álló szociológia körüli gyanakvást, egyúttal pedig megnövelték az igényeket az általa ellátni képes szociotechnikai funkciókra. Mindehhez egy szelektív közlés- és káderpolitika társult, amelyben érzékelhető volt egyfajta korlátozott pluralizmus, amelyet a nevezetes aczéli „három T"-ben (támogat - tür - tilt) fejeződött ki. Ez az előmenetel terén a szakértelem felértékelődésével és a politikai megbízhatóság súlyának viszonylagos csökkenésével járt együtt, ami lehetővé tette egyes kiváló pártonkívüli szakemberek vezető pozícióba kerülését, a legelmélyültebb felkészültséggel rendelkezők pedig még nyugati tanulmányutakra is kiutazhattak. Jellemző apróság, hogy - alighanem 
a rejtett ellenállás jeleként - csak igen kevés orosz nyelvü szociológiai könyvet rendeltek; a külföldről érkező könyvtermés java része nyugati nyelveken íródott. Az engedékenyebb politikából a szociológia társtudományai, így a korábban szintén proskribált pszichológia is profitáltak. Ez a tendencia kifejeződött abban is, hogy a desztalinizáció újabb hulláma után, 1963-ban megkezdődött a szociológia újbóli, bár a kommunista párt által szigorúan ellenőrzött és késleltetett, „fékezett habzású" intézményesülése. Ez a trend sem volt egyenes vonalú, mert az 1968-as gazdasági reform elleni neosztálinista ellentámadás nyomán visszaesés következett be, és a hatalom ökle lesújtott azokra a szociológusokra, akik ideológiai tabukat sértettek, és akiket ezért ellenzékinek, ellenségnek tekintett. Ilyen tabutémák voltak a munkásosztály vezető szerepének megkérdőjelezése, vagy annak tematizálása, hogy a kommunista rendszerben is létezik szegénység. Ilyenkor a hatalom visszatért a betiltás eszközéhez, és ismét emigrációba kényszerítette azokat, akik e tilalomfákat áthágták. Fontos és a rendszerre jellemző momentum, hogy még ez sem jelentette teljesen az ötvenes évek gyakorlatához való visszatérést, mert a külföldre elüldözés a kisebb rossz volt - elvégre a hatóságok be is börtönözhették volna azokat, akik normáikat megsértették.

A reformellenes ellentámadás azonban 1978-ban kudarccal végződött, a gazdasági reform folytatásának, a „reform reformjának” hívei pedig ismét fölénybe kerültek. Ez pedig újra kedvező környezetet biztosított a szociológiai kutatások folytatása, szociológiai tanszékek, legalább részben szociológiai profilú kutatóintézetek, folyóiratok alapítása számára. Tovább erősítette ezt a folyamatot az ország fokozódó nyugati eladósodása, ami azzal a konzekvenciával járt, hogy a magyar politikai vezetésnek immáron nemcsak a Varsói Szerződéshez, hanem a nyugati országokhoz is kellett igazodnia, azaz: kerülnie kellett a túlságosan erőszakos fellépést az ellenzékkel szemben. Ez kialakított egy félellenzéki erőteret, amely félúton volt a hivatalosság és az oppozíció között, és ennek megteremtette a nyilvánosságban a megfelelő csatornáit is. Olyan ,állami szamizdat”-fórumok jöttek létre, ahol félig szabadon lehetett publikálni, vagyis olyan közleményeket lehetett elhelyezni, amelyek nem tükrözték a hivatalos álláspontot, azzal szemben mérsékelt kritikát is megfogalmaztak, de csak egy szűk, belső szakmai körhöz juthattak el, a szélesebb publikumhoz nem. Növelte a mozgásteret az is, hogy 1984-től hivatalosan is megkezdhette müködését Magyarországon a Soros Alapítvány, ami megnövelte a nyugati tanulmányutak lehetőségeit, és ezzel új távlatokat nyitott meg a szakmai fejlődés, a nemzetközi mainstream sztenderdekkel való lépéstartás előtt. Mindezekből az előnyökből a társadalomtudományok, így a szociológia is részesedtek. A szakmai fejlődésre jellemző, hogy az évtized végére a kommunista párt társadalomtudományi intézete - amely korábban a dogmatikus marxizmus egyik fellegvára volt - a szociológia egyik legszínvonalasabb mühelyévé nőtte ki magát.

A rendszerváltás egészen 2010-ig a szociológus szakma nagyarányú fejlődését eredményezte, ugyanakkor új kihívások elé is állította a professziót. Természetesen 
megszünt a cenzúra, így egyre több szociológiai folyóirat kezdett el müködni, és új tanszékek, tudományos mühelyek jelentek meg a porondon, ami nagymértékben előmozdította a diszciplína professzionalizációját és intézményesülését. Megnyíltak a határok is, ezáltal egyre több magyar szociológus tanulhat, szerezhet tudományos fokozatot és dolgozhat nyugati országokban - ma már fel is tünik, hogy a többi társadalomtudományokhoz képest egyértelmüen a szociológia a leginkább nyugatorientált. Tehertételt jelentett ugyanakkor, hogy 1989 után sok szociológus átnyergelt a politikusi pályára. Komoly gondokat okozott az is, hogy a szociológia tanszékeket - amelyek a marxizmus-leninizmus intézetekbe lettek betagolva a pártállam idején - a rendszerváltás után ugyanúgy átvilágították, mint a filozófia, a politikai gazdaságtan és a tudományos szocializmus tanszékeken dolgozókat, holott a sokáig burzsoá áltudományként üldözött szociológia képviselői nem a dogmatikus marxizmus-leninizmust tanították. Újabb kihívást jelentett, hogy az eltömegesedett felsőoktatásban, a bolognai rendszerben a szociológusképzés - nemcsak nálunk, világszerte - egyfajta pufferszakká válik, amely azokat a hallgatókat szívja fel, akik még nem döntötték el, mik szeretnének lenni, és a szociológusi diplomát ugródeszkának tekintik a piackutatói vagy a jogi, közgazdasági, pszichológusi pálya felé. Esélyt kínál ugyanakkor, hogy a politikus továbbra is tudni szeretné, megnyeri-e a választásokat, a cégek kíváncsiak arra, el tudják-e adni a termékeiket - vagyis hogy mit gondol a szavazó, a fogyasztó - és ez is életben tartja a „pufferszakot”. A már végzett szociológusok között mindmáig jelentkező anomália a női „üvegplafon”: abnormálisan kevés nőt találunk a szakmán belül vezető pozícióban.

A 2010-es újabb rendszerváltás óta újra aggasztó tendenciák észlelhetők a professzió környezetében. Támadás indult az egyik legjobb hazai egyetem, a CEU ellen, ami a szociológusokat is hátrányosan érinti. Ahogyan az is, hogy a hadjárat új célpontokat talált: elérte a társadalmi nemek képzést és a Magyar Tudományos Akadémiát is; az utóbbi esetében az sem lehet mentség, hogy sok szempontból az 1989 elötti rezsim örököse. Mindez azért különösen aggályos, mert a szociológia - ha társtudományaival összehasonlítjuk - nagyon erősen kutatásorientált; itt nem elég a papír és a ceruza, ide komoly kutatási pénzekre van szükség. Sajnos, kezdenek visszatérni azok az idők, amikor a szociológiát összekeverték a szocializmussal, és a szerzőknek nemcsak a szakmájuk szabályaira kellett figyelniük, hanem arra is, hogyan játsszák ki a cenzort.

Az amerikai, a német vagy a francia szociológia történetével foglalkozó termés jóval nagyobb, mint a hazai - elvégre ezekben az országokban ez a tudományág a mienknél zavartalanabb, és ezért gazdagabb múltra tekinthet vissza. Némedi Dénes, Nagy J. Endre, Litván György, Kupa László, Szabari Vera, Saád József, Tóth Pál Péter könyvei, cikkei egy-egy korszakkal vagy egyes szerzőkkel foglalkoznak. Egyedül Huszár Tibor A magyar szociológia története címủ 2015-ös müve vállalkozott arra, hogy a diszciplína fejlődéséről a kezdetektől máig terjedő áttekintést 
nyújtson, de az intézménytörténet helyett a föbb irányzatok és a legkiemelkedőbb egyéniségek bemutatását tüzte ki céljául. Én - teoretikus hajlamomnál fogva - inkább az ilyen jellegű szociológiatörténeti munkákat preferálom, de a szakma nagy öregje e kései opuszában elmaradt várakozásaimtól, mert inkább a némileg önkényesen kiválasztott szerzők müveinek helyenként ötletszerü taglalását nyújtotta.

Karády és Nagy kötete nem bocsátkozik annak taglalásába, hogy mi tekinthető szociológiának, és mi nem. Szerzői például gyakran azt veszik alapul, hogy az általuk átnézett sajtóorgánumok számára mi jelenik meg szociológiaként, és hányszor említik a ,szociológia” szót. Így nem mennek bele annak boncolgatásába sem, hogy mi a különbség egyfelől a társadalmi problémákat fürkésző publicisztika vagy szociográfia, másfelől a mai értelemben vett professzionális szociológia között. A definíciós precízkedéstől való örizkedésnek megvan az az elönye, hogy így a szélesebb társadalomtudományos és társadalmi kontextusba ágyazva - ha úgy tetszik: szociológiai nézőpontból - taglalható a szociológia fejlődése. A Sociology in Hungary igen széles kitekintésben ír szociológiai - és preszociológiai, kváziszociológiai, félszociológiai - tanszékekről, folyóiratokról, kutatóintézetekről, kutatási projektekről éppúgy, mint a rokon diszciplínák hasonló szervezeti infrastruktúrájáról, ahogy a jelentősebb szerzőkről is (igaz, mindegyikről csak lexikoncikknyi terjedelemben, de a lényeget jól összefoglalva). Mindezt remekül egészítik ki - és ez a könyv egyik fö erénye, ami a big data korában különösen fontos - az alapos statisztikák. Külön táblázatok foglalkoznak az egyes újságokban, folyóiratokban hivatkozott vagy szemlézett szociológiai tárgyú cikkek, illetve publikált könyvek anyanyelv szerinti megoszlásával. Érdemes végigkísérni, hogy az egyes rendszerváltások után hogyan csökkent a korábbi rezsimben erős pozíciót kivívott szerzők idézettsége - ez alól csak Erdei és Szalai Sándor képez kivételt. Meglepő, hogy a hetvenes évektől kezdve milyen népszerüségnek örvendett Bourdieu, és ehhez képest milyen kevés említés esik Foucault-ról. Szintén nagyon informatív, ahogyan adatokkal alaposan körüljárják az 1989 utáni fejlődést és professzionalizálódást, ami a doktori iskolák és a különböző tudományos fokozatok megszerzése terén mutatkozó elörelépéssel mérhetö. Ugyanakkor, mivel az adatok minden esetben országsorosak, a sok tekintetben jelentős határon túli magyar szociológia taglalására - ahogy az a címben szereplö „in Hungary” kitételből is látható - nem kerülhetett sor.

Dióhéjban a fentiekben foglalható össze az a történet, amit a szerzők elmesélnek. A dolog természetéből adódóan a szakmabelieknek viszonylag kevesebb nóvummal szolgál a kötet, elvégre honfitársainknak egy rövidebb bédekker kevesebbet nyújt, mint a külföldi turistáknak. Mindazonáltal külön erénye már az is, hogy megszületett, mert a magyar szociológia veszternizáltsága következtében mindeddig méltatlanul kevés figyelem jutott hazai gyökereinek. Természetesen a választott megközelítésnek megvannak a maga korlátai is. Az, hogy a szerzők számára szociológia az, amit mások annak tekintenek, annyiban érthető, hogy egy 
professzionalizációjában sokszorosan korlátozott, évtizedekig csak formálódóban levő foglalkozást tüznek górcső alá. Becskeházi és Kuczi Valóság 70’ címü remek könyve azonban például a Valóság címủ folyóiratról szólva mélyebbre ás, amikor azt boncolgatja: a hetedik évtizedben az orgánum hasábjain meglepően sok szociológiainak feltüntetett írás jelent meg, amit valójában dilettáns tanárok, népművelők írtak. Arra is érdemes lett volna kitérni, hogy nem volt-e zsákutca a nyolcvanas években a szociológiát a marxista tanszékcsoportokba integrálni, és egyúttal kötelező tantárggyá, vagyis redisztributív jószággá tenni, ami egy piacgazdaságban nyilván nem fenntartható, ugyanakkor hamis (lét)biztonságérzetet keltett. E kisebb hiányosságokkal együtt összességében a két neves társadalomtörténész munkája azért is ígéretes, mert - bár egyelőre határainkon kívüli befogadókat céloz meg megnövelheti az érdeklődést a hazai szociológia hagyományai iránt. 